\title{
PLUTARCH O GRECKICH I RZYMSKICH ŻOŁNIERZACH
}

\author{
Lucyna Kostuch
}

Uniwersytet Jana Kochanowskiego w Kielcach

\author{
ABSTRACT \\ PLUTARCH ON GREEK AND ROMAN SOLDIERS
}

It is not easy to find interest in soldiers and army issues in the source literature which is devoted to Plutarch. However, considering only the statistical point of view, it should be noted that Parallel Lives is a huge base of information related to ancient soldiers. The goal of the presented article is to recreate the image of a soldier created by Plutarch in his works, especially in Parallel Lives. Although military commanders were also soldiers, the interest is focused on regular participants of military efforts who are considered as an army in general, especially because Plutarch often confronts them with main characters of his biographies. The article is an effort to find an answer to the following questions: Was Plutarch interested in military issues? Do Parallel Lives create a consistent image of a soldier, or are we just presented with some disconnected observations considering different historical conditions which are continuously changing? Which of the soldier's types from the ancient literature are dominant in Parallel Lives and thus, which of the soldiers was immortalised by Plutarch?

Key words: soldiers, Plutarch, Parallel Lives.

Słowa kluczowe: żołnierze, Plutarch, Żywoty równoległe.

Laurie Brink, charakteryzując żołnierzy w literaturze antycznej (w jednym z rozdziałów opracowania Soldiers in Luke-Acts. Engaging, Contradicting, and Transcending the Stereotypes), zwróciła uwagę, że największe ich nagromadzenie występuje w dziełach historyków, a z dużą częstotliwością pojawiają się w komedii i noweli ${ }^{1}$. Wśród przydatnych źródeł informacji autorka wymieniła również dzie-

1 L. Brink, Soldiers in Luke-Acts. Engaging, Contradicting, and Transcending the Stereotypes, Tübingen 2014 (rozdział The Characterization of Soldiers in Greco-Roman Literature), s. 42-53; na temat żołnierzy w antycznej komedii zob. H. Wysk, Die Gestalt des Soldaten in der griechisch-römischen Komödie, Giessen 1921; W.T. MacCary, Menander's Soldiers: their Names, Roles and Masks, „American Journal of Philology” 1972, 93, s. 279-298; H.D. Blume, Komische Soldaten. Entwicklung

Adres do korespondencji: lucyna.kostuch@ujk.edu.pl 
ła Plutarcha ${ }^{2}$, jednak prawie zupełnie ich nie wykorzystała. W jej pracy nie ma ani jednego odwołania do Plutarchowych Żywotów. W innym opracowaniu na bardzo podobny temat A. Kyrychenko poświęcił stosunkowi Plutarcha do żołnierzy, wyłącznie rzymskich, zaledwie cztery strony pobieżnej analizy, gdyż nie był to główny przedmiot badań autora ${ }^{3}$. W literaturze przedmiotu poświęconej Plutarchowi nie dostrzegamy zainteresowania problematyką żołnierską i sprawami wojskowymi co najwyżej analizą zostają objęte pojedyncze Żywoty albo żołnierze pojawiają się na marginesie rozważań ${ }^{4}$. Tymczasem, biorąc pod uwagę choćby tylko statystyczny punkt widzenia, należy stwierdzić, że Żywoty równoległe stanowią ogromną bazę informacyjną na temat antycznych żołnierzy. Choć ich prezentacja nie była oczywiście głównym celem biografa, to jednak pojawiają się w każdym z Żywotów. Plutarch regularnie operuje w wojennym kontekście terminami: żołnierz (stratiōtēs), żołnierze (stratiōtai), wojsko (stratia), jak również bardziej precyzyjnymi pojęciami, np. hoplici (hoplitai) czy konnica (hippeis), a także używa w znaczeniu synonimicznym określeń, takich jak ludzie (andres), Ateńczycy, Platejczycy, Rzymianie itd., mając na myśli armie obywatelskie i walczące ludy. Celem prezentowanego artykułu jest odtworzenie obrazu żołnierza, który stworzył Plutarch w swoich pismach, głównie w Żywotach równolegtych. Choć wodzowie również byli żołnierzami, przedmiotem zainteresowania uczynimy zwykłych uczestników militarnych zmagań, którzy mieszczą się w pojęciu „wojsko”, tym bardziej że Plutarch częstokroć przeciwstawia ich głównym bohaterom biografii. Rodzą się zatem następujące pytania: Czy Plutarch interesował się problematyką wojskową? Czy z Żywotów wyłania się jeden spójny obraz żołnierza, czy raczej mamy do czynienia z obrazami, biorąc pod uwagę zmieniające się w dziele uwarunkowania historyczne? Które z żołnierskich typów obecnych w antycznej literaturze dominują w Żywotach, a tym samym jakiego wojaka Plutarch unieśmiertelnił?

Rozważania należałoby zacząć od ustalenia wojskowych kompetencji Plutarcha i poziomu zainteresowania sprawami oręża. Choć sam Plutarch żył już w czasach Pax Romana, trzeba pamiętać, że wojna odcisnęła w odległej przeszłości silne piętno na jego rodzinnej miejscowości - Cheronei. Wojenne doświadczenia nie były obce jego bliskim przodkom. Od niego samego dowiadujemy się, że Marek Antoniusz wysługiwał się jego pradziadkiem Nikarchosem i innymi obywatelami miasta podczas zmagań pod Akcjum ${ }^{5}$. Niestety nie mamy powodu przypuszczać, że biograf posiadał

und Wandel einer typischen Bühnenfigur in der Antike [w:] Rezeption des antiken Dramas auf der Bühne und in der Literatur, red. B. Zimmermann, Stuttgart-Weimar 2001, s. 175-195; żołnierze w noweli zob. J. Hilton, War and Peace in the Ancient Greek Novel, „Acta Classica” 2005, 48, s. 57-85.

2 L. Brink, op. cit., s. 56.

A. Kyrychenko, The Roman Army and the Expansion of the Gospel: The Role of Centurion in Luke-Acts, Berlin 2014 (rozdział The Roman Soldiers in Greco-Roman Literature), s. 74-77.

${ }^{4}$ Np. L. de Blois, Soldiers and Leaders in Plutarch's Galba and Otho [w:] A Roman Miscellany. Essays in Honor of Anthony R. Birley on his Seventieth Birthday, red. H.M. Schellenberg, V.E. Hirschmann, A. Krieckhaus, Gdańsk 2008, s. 5-13; idem, Crossing Status Barriers: the Disruption of an Imperial Banquet by Angry Soldiers in Plutarch's Otho [w:] Symposion and Philantropia in Plutarch, red. J.R. Ferreira, D. Leao, M. Tröster, Coimbra 2009, s. 223-229.

5 Plut. Ant. 68.4. 
żołnierskie doświadczenie ${ }^{6}$. Efebia w czasach imperium rzymskiego utraciła w dużej mierze swój militarny charakter ${ }^{7}$. Nie dysponujemy też dowodami, że Plutarch zaczytywał się w podręcznikach wojskowych, choć o znajomości taktyki i strategii Pyrrusa zdaje się wnioskować na podstawie pism (peri taxeis kai stratēgias epistēmēs), które na ten temat zostawił epirocki król ${ }^{8}$. Plutarch sporo pisze o Kineaszu z Tesalii ${ }^{9}$, o którym skądinąd wiemy, że streścił dzieła Eneasza Taktyka, a także wspomina o tym, że Filopojmen korzystał z ilustrowanej Taktyki Ewangelosa ${ }^{10}$. W Żywocie Aleksandra Plutarch deklaruje, że innym pisarzom pozostawia opisywanie wielkich zmagań wojennych (easantas heterois ta megethē kai tous agōnas) - bitew, w których padały tysiące zabitych - ustawianie do walki olbrzymich armii i obleganie potężnych miast ${ }^{11}$. I choć, jak zauważył E.A. Wardman, brzmi to jak protest przeciwko historii wojennej ${ }^{12}$, lektura biografii Aleksandra i innych Żywotów nie pozwala uznać tej deklaracji za przyjętą metodę. Trzeba pamiętać, że głównymi źródłami Plutarcha pozostawały dzieła historyczne ${ }^{13}$, a w tych, jak wiadomo, zdecydowanie dominowały wojna, wojsko, bitwy i broń. Nie możemy dać się zwieść opowieści Plutarcha o pewnym człowieku, który po przeczytaniu kilku ksiąg Efora zanudzał wszystkich historią bitwy pod Leuktrami, czy stwierdzeniem, że wojskowi lubią opowiadać o wojnach ${ }^{14}$. Herodotowi przecież zarzuca Plutarch, że nie zaprezentował szyków Hellenów, nie podał, w którym miejscu walczyła flota każdego z państw, i że więcej słów poświęcił Artemizji niż całej bitwie pod Salaminą ${ }^{15}$. Jak wielu przed nim i po nim uważał, że o wojnie powinni rozprawiać tylko ci, którzy sami wojowali ${ }^{16}$. Plutarch, choć najpewniej sam nie wojował, stara się dokładnie opisać militarne zmagania: plany kampanii wojennych i poszczególnych bitew ${ }^{17}$, miejsca walk ${ }^{18}$, liczbę wojsk ${ }^{19}$, usta-

6 Biografia Plutarcha zob. K. Ziegler, Plutarchos, RE 22, 1 (1951), s. 636-962; D.A. Russell, Plutarch, London 1972.

7 Zob. P. Roesch, Une loi fédérale béotienne sur la préparation militaire [w:] Acta of the Fifth International Congress of Greek and Latin Epigraphy, Oxford 1971, s. 81-88; N.M. Kennell, The Greek Ephebate in the Roman Period, „The International Journal of the History of Sport” 2009, 26, s. 323-342.

8 Plut. Pyrrh. 8.2.

9 Plut. Pyrrh. 14, 15.1, 16.1, 18.2-3, 19.3-4, 20.1-4, 21.3, 22.3; por. Ael. Tac. 1.1.

10 Plut. Phil. 4.4.

11 Plut. Alex. 1.

12 A.E. Wardman, Plutarch's Methods in the Lives „Classical Quarterly” 1971, 21, s. 254, 258, 260-261.

13 Zob. syntetycznie na temat źródeł wykorzystanych przez Plutarcha w Żywotach (wraz z bibliografią): M.T. Schettino, The Use of Historical Sources [w:] A Companion to Plutarch, red. M. Beck, Malden Mass.-Oxford 2014, s. 417-436; zob też m.in.: C.B.R. Pelling, Plutarch and History. Eighteen Studies, Oxford 2002; P.A. Stadter, Plutarch and His Roman Readers, Oxford 2014.

14 Plut. De Garr. 22.

15 Plut. De Herod. 34, 43.

16 Plut. De Sera 4; por. np. Plb. 12.25g, 25h, 28g; Luc. Hist. conscr. 29.

17 Na przykład: Plut. Arist. 8.2-6, 16.1-2; Them. 7.1, 11.2-4, 12.3-4, 16.1-3; Nic. 14.3, 20.4; Cleom. 20.1-3, 25.3-4, 27; Crass. 16.2-3; Luc. 9.2, 14.4-6.

18 Na przykład: Plut. Them. 8.2-3; Lys. 28-29; Tim. 27.2-3; Alex. 20.1-4; Pyrrh. 21.5-6; Fab. 11.1-2; Flam. 8.1-2; Sull. 16.1, 17.3-5, 20.4-5.

19 Na przykład: Plut. Them. 14.1; Nic. 21.1; Alc. 20.1; Tim. 12.3; Alex. 15.1, 66.2; Sull. 24.1; Pomp. 11.2, 26.2, 64.1; Crass. 19.1; Luc. 8.2, 26.6; Ant. 61.1. 
wienie armii lub okrętów ${ }^{20}$, straty w ludziach ${ }^{21}$. Prezentuje broń (miecze, włócznie, tarcze, pancerze, oszczepy, hełmy, łuki) ${ }^{22}$, machiny oblężnicze ${ }^{23}$, okręty wojenne ${ }^{24}$. A oprócz tego wielokrotnie ukazuje obozy wojskowe i żołnierskie życie, żołnierzy pokonujących naturalne przeszkody, żołnierzy biorących udział w podstępach wojennych i grabiących miasta. Nie pomija również problemów związanych z zaopatrzeniem armii i wywiadem wojskowym. Sporo pisze o zwierzętach bojowych i pociągowych. W Żywotach pojawiają się częstokroć detale pozwalające odtworzyć szczegółowy obraz walk, np. groty, które przeleciały tuż koło końskiego ogona, otarły się prawie o siebie i utkwiły $\mathrm{w}$ ziemi ${ }^{25}$, oraz podaje szczegółowe informacje dotyczące żołnierskiego życia, np. dowiadujemy się, kiedy rzymscy żołnierze po raz pierwszy zobaczyli wielbłądy ${ }^{26}$. Dodatkowo, jak zauważył F. Fuhrmann, Plutarch często posługuje się w swoich pismach metaforyką militarną ${ }^{27}$. Co istotne, w Żywotach mowa jest nie tylko o całej armii, ale również o pojedynczych żołnierzach, których imiona Plutarch utrwala ${ }^{28}$. A trzeba zaznaczyć, że prawdziwe zainteresowanie przeciętnym żołnierzem oraz jego postawą moralną zrodziło się w literaturze antycznej późno, bo dopiero w czasach imperium rzymskiego ${ }^{29}$. Plutarch ma również świadomość przemian, które przez wieki zachodziły w dziedzinie wojskowości. Doskonale też zdaje sobie sprawę, że upływ czasu stanowi przeszkodę do poznania minionej rzeczywistości ${ }^{30}$. Dowodem tego, że Plutarch brał pod uwagę uwarunkowania historyczne wojennych instytucji może być jego wnioskowanie na temat konieczności szukania różnic między triumfem a owacją w dawnych (palaios) $\operatorname{czasach}^{31}$. Z pewnością Plutarcha nie fascynowały sprawy oręża i nie one motywowały go do pisania Żywotów ${ }^{32}$. Nie był wybitnym znawcą problematyki wojskowej i przedkładał pokój

20 Na przykład: Plut. Arist. 18.2-4; Nic. 19.2, 19.5; Lys. 10.2; Tim. 27.2-5; Pyrrh. 16.6, 17.1, 21.6; Fab. 16.1-2; Sull. 17.7, 27.5; Pomp. 69.4; Crass. 23.3-4; Luc. 27.4-6; Ant. 42.1.

21 Na przykład: Plut. Arist. 19.3-5; Lys. 28.6; Tim. 28.5, 31.4; Alex. 11.6; 16.7; Eum. 14.2; Publ. 9.3, 17.1; Marc. 12.3, 29.9; Mar. 27.3; Sull. 14.3, 28.8; Pomp. 32.7, 67.6; Caes. 15.3.

${ }_{22}$ Na przykład: Plut. Arist. 18.3; Ages. 18.3; Tim. 4.2; Alex. 32.5-6; Eum. 7.3-5, 7.7; Pyrrh. 22.5, 34.1-3; Cleom. 11.2; Phil. 9.1-5; Marc. 12.2; Aem. 20.2; Sull. 18.4, Crass. 24-27; Luc. 7.4, $28.3-4$.

23 Na przykład: Plut. Per. 27.3; Nic. 18.3; Tim. 13.3, 17.3; Alex. 24.3; Eum. 8.5; Demert. 20.1, 39.2; Marc. 14-15, 17; Sull. 12.1-2; Sert. 6.5; Luc. 10.2-3, 37.2; Ant. 38.2-3.

24 Na przykład: Plut. Them. 4, 14; Cim. 12.2; Per. 26.2-3; Alc. 16.1; Lys. 3.3; Dio 25.1; Luc. 3; Ant. 63, 65-66.

25 Plut. Sull. 29.5

26 Plut. Luc. 11.4.

27 F. Fuhrmann, Les images de Plutarque, Paris 1964, s. 254-257.

28 Na przykład: Plut. Arist. 5.3, 17.7, 19.1; Nic. 25.2; Alex. 39.2, 41.5, 70.3-4; Pyrrh. 28.3-4, 30.4, 34.3; Cleom. 8.1, 37.6; Cam. 25.1-2; Cat. Ma 13.3; Marc. 10.2; Fab. 20.1-2; Mar. 14.3-5; Sull. 14.2, 17.6, 19.5; Caes. 16, 44.5-6; Pomp. 71.1; Brut. 49.2; Ant. 74.

${ }_{29}$ Zob. L. Brink, op. cit., s. 45-48.

30 Na przykład: Plut. Thes. 1, 27.5; Lyc. 1.3; Cim. 3.2; Per. 13.12.

31 Plut. Marc. 22.

32 P.A. Stadter, op. cit., s. 262, przypis 21. 
nad wojnę ${ }^{33}$. Jednak trzeba zauważyć, że doceniał znakomite czyny wojenne ${ }^{34}$. Starał się przy tym - jak sam deklaruje - ich nie umniejszać ani nie powiększać ${ }^{35}$. Zatem, podsumowując, należy stwierdzić, że Plutarch nie uchyla się w Żywotach od opisu broni, operacji wojskowych i co najważniejsze - żołnierzy.

Jak zadeklarowano, przedmiotem prezentowanego artykułu są zwykli żołnierze, których Plutarch często przeciwstawia wodzom. $Z$ założenia dystans między nimi ujawniają nawet porównania, niekoniecznie o negatywnej wymowie ${ }^{36}$. Wydaje się, że kadrze oficerskiej, której zasadniczo nie zalicza się do szeregowców, bliżej w Żywotach do prostych żołnierzy niźli do wodzów - ci zdają się osamotnieni. Oczywiście sprawa nie zawsze jest taka prosta, bo przecież Plutarch, o ile to zasadne, prezentuje karierę wojskową swoich bohaterów, którzy nie od razu stawali się wodzami. Kolejna rzecz - gdy mowa o prostym żołnierzu z historycznego punktu widzenia, musimy pamiętać, że nie jest on równoznaczny z prostym człowiekiem. Przed inicjatywą wojskową Gajusza Mariusza trzon armii greckich i rzymskiej zasadniczo stanowili dość majętni obywatele, częstokroć nieodbiegający ogólnym wykształceniem i kulturą od swoich dowódców i wodzów. Przyjmuje się, że proces narastania psychologicznego dystansu między wodzem (stratēgos) a żołnierzami (stratiōtai) w antycznych armiach rozpoczął się po roku 338 p.n.e., a więc w armii Filipa II przejętej przez Aleksandra Wielkiego, jednak zdaniem E.L. Wheelera początku ewolucji można upatrywać już w klasycznej falandze ${ }^{37}$. Sam Plutarch żył w czasach, gdy wódz od kilku wieków otoczony był nimbem boskości, zaś rzymska armia miała charakter zawodowy, tak więc pozostawała otwarta dla szerokiego ogółu.

Rodzi się pytanie, zasadnicze w kontekście formuły Żywotów: czy Plutarch porównuje żołnierzy greckich z rzymskimi, a w konsekwencji czy dostrzega dające się ująć w ogólne ramy różnice między nimi? (Dodajmy, że dla biografa Pyrrus i Aleksander Wielki to reprezentanci świata greckiego ${ }^{38}$ ). Okazuje się, że biograf rzadko wykorzystuje taki paralelny układ. Owszem, porównuje żołnierzy Tymoleona z żołnierzami Emiliusza Paulusa i wojsko Filopojmena z wojskiem Tytusa Flamininusa, jednak uwagi te nie mają generalizującego charakteru ${ }^{39}$. Możemy się jedynie domyślać, że

33 Plutarch jako orędownik pokoju zob. G. Zampaglione, L'idea della pace nel mondo antico, Torino 1967, s. 240-241; A. Bravo García, El pensamiento de Pluraco acerca de la paz y de la guerra, „Cuadernos de Filología Clásica” 1973, 5, s. 141-191; B. Gray, Reconciliation in Later Classical and Post-Classical Greek Cities: A Question of Peace and Peacefulness? [w:] Peace and Reconciliation in the Classical World, red. E.P. Moloney, M.S. Williams, New York 2017, s. 76-77.

34 Na przykład: Plut. Cim. 3.1-2; Per. 1-2; Tim. 37.3; Dem. 20.1-2; Sull. 6.2-3; Pomp. 8.6; Caes. 15; por. De Alex. 1; De Herod. 15; Non Posse 18; An Seni 6.

35 Na przykład: Plut. Cim. 2.3; De Herod.; zob. J. Marincola, History Without Malice: Plutarch Rewrites the Battle of Plataea [w:] Brill's Companion to the Reception of Herodotus in Antiquity and Beyond, red. J. Priestley, V. Zali, Leiden-Boston 2016, s. 101-119.

36 Na przykład: Plut. Arist. 12.2; Per. 12.7; Pel. 2.4; Agis 14.3; Fab. 4.3; Mar. 7.3; Luc. 33.2; Cat. Mi. 9.4; Ant. 2-3.

37 E.L. Wheeler, The General as Hoplite [w:] Hoplites. The Classical Greek Battle Experience, red. V.D. Han son, London-New York 1991, s. 121-170.

38 Aleksander stał się greckim bohaterem w okresie hellenistycznym, zob. np. T. Whitmarsh, Alexander's Hellenism and Plutarch's Textualism, „Classical Quarterly” 2002, 52, s. 174-192.

39 Plut. Comp. Tim. Aem 1.2; Comp. Phil. Flam. 2.1. 
Plutarch uważał Hellenów ogólnie za mniej wojowniczych od Rzymian, o czym - jak sądzi S. Hornblower - świadczyłaby na przykład konkluzja w Porównaniu Eumenesa z Sertoriuszem, w której podkreśla miłość Eumenesa do wojny i umiłowanie pokoju Sertoriusza, tak jakby było to coś nienaturalnego ${ }^{40}$. W istocie, gdyby przyjąć statystyczny punkt widzenia, w ,greckich” Żywotach żołnierze pojawiają się rzadziej niż w „rzymskich”. Nie oznacza to jednak, że Plutarch nisko oceniał walory helleńskich armii. Wyraźnie stwierdza, że greccy dowódcy potrafili planowo prowadzić wojny i odnosić zwycięstwa na lądzie i na morzu ${ }^{41}$. Pomimo że - jak już wspomniano Plutarch posiada świadomość historycznych przemian w dziedzinie wojskowości, a także dostrzega proces upadku obyczajów żołnierskich ${ }^{42}$, w Żywotach zdaje się funkcjonować pewien mechanizm, wedle którego działają wszyscy żołnierze wtłoczeni w kanon zalet i przywar, niezależnie od tego, czy mowa o greckich armiach obywatelskich, macedońskiej i hellenistycznej falandze, legionach dawnej republiki rzymskiej, czy kohortach gromadzonych przez wielkich wodzów u jej schyłku. Między Żywotami „greckimi” a „rzymskimi” dostrzegamy różnice ilościowe, a nie jakościowe. Greccy żołnierze Plutarcha mają te same wady, tyle że ujawniają je w mniejszym natężeniu, co może oczywiście wynikać z patriotycznych pobudek i sentymentu Plutarcha do bohaterskiej przeszłości świata greckiego, ale równie dobrze z posiadanych źródeł, które prezentują heroiczny model helleńskiego wojownika. Stosunek Plutarcha do rzymskiej cywilizacji był pozytywny, choć nie bezkrytyczny, więc raczej nie chodziło o celowe zdyskredytowanie rzymskich żołnierzy ${ }^{43}$. Nie wydaje się, by biograf dostrzegał zasadnicze różnice w moralnej postawie żołnierzy piechoty, konnicy i floty. Plutarch nie jest też oryginalny, dopatrując się w żołnierzach wojsk najemnych (misthophoroi) tradycyjnych skłonności do przekupstwa i niestałości. To, co różni ich od żołnierzy wojsk regularnych, to fakt, że nic nie wiedzą o pracy na roli, żeglowaniu, hodowli, a w zamian oddają się jednej tylko sztuce (technē) - wojowaniu ${ }^{44}$. Dostrzegalne odmienności między armiami różnych ludów, państw czy wodzów Plutarch stara się umieszczać w ramach spectrum, a nie na osi czasu. I tak na przykład spośród Greków za najbardziej wojowniczych, obeznanych z wojaczką (polemikos) uznaje Kreteńczyków i Lacedemończyków ${ }^{45}$. Rzymianie - jak zaznacza - za najbardziej waleczne plemiona (polemikōtata phyla) uważali Samnitów i Lukanów. $\mathrm{W}$ armii lacedemońskiej wady żołnierskie uwidaczniały się w najmniejszym stopniu, a w wojsku Sulli i Lukullusa - w natężeniu ogromnym, które znów znacznie zmalało w kohortach galijskich Juliusza Cezara i wojsku Marka Antoniusza maszerującym na

40 Plut. Comp. Eum. Sert. 2.1; S. Hornblower, Warfare in Ancient Literature: The Paradox of War [w:] The Cambridge History of Greek and Roman Warfare, vol. I, red. P. Sabin, H. van Wees, M. Whitby, Cambridge 2008, s. 27.

41 Plut. Flam. 11.4.

42 Na przykład: Plut. Per. 9.1; Agis 6.1-2, 14; Cleom. 9.3; Marc. 3.2, 22. 2-5, Flam. 11; Sull. 1.3, $12.7-9$.

43 Między innymi: C.P. Jones, Plutarch and Rome, Oxford 1971; por.: S.C.R. Swain, Plutarch, Chance, Providence and History, „American Journal of Philology” 1989, 110, s. 272-302; idem, Hellenic Culture and the Roman Heroes of Plutarch, „Journal of Hellenic Studies” 1990, 110, s. 126-145.

44 Plut. Ages. 36-37; Pel. 27; Aem. 12.2.

45 Plut. Comp. Phil. Flam. 2.2, Marc. 22.5. 
Partów. Znajdujemy też w Żywotach wartościujące określenie „barbarzyński” (barbarikos), z którym Plutarch łączy w wojsku brak dyscypliny, arogancję, wystawność, pretensjonalność i skłonność do przesądów ${ }^{46}$.

Zanim przejdziemy do ustalenia, jaki typ żołnierza dominuje w Żywotach, należy zacząć od oczywistego stwierdzenia, że biograf nie tworzył w literackiej próżni, a dodatkowo nie mógł być całkiem obojętny na stereotypowy wizerunek żołnierza funkcjonujący w jego czasach. W opracowaniu Brink, które stało się punktem odniesienia w niniejszych rozważaniach, odnajdujemy przydatną żołnierską typologię stworzoną na podstawie greckich i rzymskich źródeł różnych gatunków literackich, począwszy od Homera, która dalej posłuży za szkielet rozważań. W pozytywnym wariancie (anēr agathos) mamy na polu bitwy żołnierza dzielnego, karnego, bogobojnego, w kategorii negatywnej - tchórza, buntownika, chciwca, brutala. Po powrocie do domu żołnierz może stać się dobrym, skromnym obywatelem lub samochwałą. Z zebranego przez Brink materiału źródłowego (z którego, pomimo deklaracji autorki, Plutarch jest wyłączony) wynika, że w najmniejszym stopniu antyczni autorzy byli skłonni opisywać tchórza, a w czasach, w których żył Plutarch, w literaturze dominuje negatywny typ brutalnego buntownika ${ }^{47}$. Oczywiście tego typu analiza z natury rzeczy musi nosić znamiona powierzchowności. Przychodzi na myśl wątpliwość, czy w ogóle można porównywać mentalność greckich żołnierzy armii obywatelskiej dowodzonej przez Arystydesa czy Temistoklesa z macedońskimi wojakami Aleksandra Wielkiego, najemnikami hellenistycznych królów i zmierzającymi do profesjonalizacji legionistami Gajusza Mariusza oraz czy prezentacja wojowników w dziełach Tukidydesa i Ksenofonta znajduje prostą analogię w pismach Salustiusza czy Juliusza Cezara, jeśli pozostaniemy w obrębie tego samego gatunku literackiego. Nawet jeśli obejmiemy analizą wyłącznie historyczno-biograficzną spuściznę literacką schyłku republiki i pierwszego wieku pryncypatu, uznając ten okres za „epokę” Plutarcha, to i tak czekają nas niespodzianki. Jak zwrócił uwagę Kyrychenko, obraz żołnierza stworzony przez Cezara nie odpowiada funkcjonującemu stereotypowi prezentując siebie jako doskonałego wodza, przydał on swoim wojakom zdecydowanie pozytywnych $\mathrm{cech}^{48}$. Niewątpliwie musimy więc liczyć się z tym, że Plutarch $\mathrm{z}$ jednej strony pozostawał uzależniony od ogromu źródeł różnych gatunków, pochodzących z różnych okresów dziejów i napisanych w różnych celach, a z drugiej strony był obciążony funkcjonującym współcześnie żołnierskim stereotypem.

Analiza $\dot{Z} y$ wotów dowodzi, że Plutarch nie szafuje w stosunku do żołnierzy określeniami oznaczającymi dzielność, męstwo, odwagę (andragathia, andreia, tolma, aretē itp. $)^{49}$. Powyższe określenia pozostają w biografiach rozproszone, koncentrują

46 Na przykład: Plut. Pel. 34.2; Dio 35.3; Alex. 24.2; Eum. 13.5; Pyrrh. 16.4-5; Sert. 11.3, 16.1.

47 L. Brink, op. cit. (rozdział Literary Stereotypes of Greco-Roman Soldiers), s. 61-91.

48 A. Kyrychenko, op. cit., s. 49-51, 73.

49 Dzielni żołnierze (często za sprawą wodza): Plut. Lyc. 21.3-4; Arist. 11.9, 12.2, 16.4, 17, 18.1, 21.5; Them. 7.3, 8.2, 15.2; Cim. 13.2, 17.4-5; Per. 18.3, 35.1; Nic. 17.3, 27.6; Ages. 16.4, 22.2; Pel. 15.2, 17.6, 23.4; Dio 22.5; Tim. 20.2, 21.3; Alex. 11.5, 24.1; Demetr. 48.2; Pyrrh. 21.10, 28.4, 29.3; Arat. 37.2; Cleom. 28.1; Phil. 9.6; Flam. 7.3; Aem. 21.2; Mar. 16.4-5; Sull. 27.5; Luc. 29.5; Crass. 26.6; Pomp. 8.2, 70.2; Cat. Mi. 9.3, 54.5-6; Caes. 16, 17.1, 40.1; Ant. 42.3, 43.2, 45, 49.2, 68.3; Comp. Phil. Flam. 2.1. 
się w istotnym stopniu w Żywocie Arystydesa, a to za sprawą dawnych agathous andras broniących Hellady przed Persami. To oczywiste, że dzielni żołnierze (andres agathoi) stoją w cieniu głównych bohaterów biografii, przy których imionach o wiele częściej pojawiają się przymiotniki, takie jak mężny, odważny, silny (andreios), wojowniczy, waleczny, biegły w sztuce wojennej (polemikos) ${ }^{50}$. Jednak wydaje się, że Plutarch miał dodatkowy powód, by tak uczynić. W Żywocie Lukullusa zdradza swoje poglądy, gdy pisze, że niemały udział w osiągnięciach wojennych rzymskiego wodza miało wojsko (stratia) ${ }^{51}$, zupełnie tak jakby było to coś nienaturalnego. W istocie z Żywotów wynika, że jedynie wyjątkowo żołnierze przewyższali wodza dzielnością, jak to miało miejsce pod Akcjum, gdy Antoniusz uciekł, a jego ludzie bili się nadal, zachowując wierność (pistis) i okazując męstwo (aretē) ${ }^{52}$. Żołnierski zapał (prothymia, enthousiasmos) niezależny od postawy i działań dowódcy wydaje się nie należeć do Plutarchowej reguły. Przykładem odstępstwa mogą być Ateńczycy, którzy w walce z Samijczykami doświadczyli takiej chęci walki, że trudno było ich powstrzymaćs3. Dumni obywatele ateńskiej polis przypisali sobie, a nie Miltiadesowi, zasługę zwycięstwa pod Maratonem ${ }^{54}$. Oddolna inicjatywa miała również wpływ na Aleksandra Macedońskiego, którego natchnął gorliwością (hormē) i zapałem (prothymia) widok własnych żołnierzy ogarniętych entuzjazmem (enthousiasmos) ${ }^{55}$. Podobnie Agisa podnieciła ambicja (philotimia) i zapał (prothymia) widoczne u idących z nim na wyprawę wojenną ${ }^{56}$. Innym przykładem jest Sulla, który rozgromił przeciwnika bez ustawiania wojska w szyku bojowym, wykorzystując jedynie powszechny zapał (prothymia) i wzmożoną odwagę (tolma) żołnierzy ${ }^{57}$. Taki żołnierski entuzjazm był jednak niebezpieczny i mógł okazać się zwodniczy, czego dowodem jest klęska Demostenesa, którego tak olśniła siła $(r h o ̄ m e \overline{)}$ i zapał (prothymia) wojska, że ogarnięty radością, zignorował niekorzystne wróżby ${ }^{58}$. Czasem w stan nadzwyczajnej gotowości bojowej popadali poszczególni żołnierze, np. taki, który położył trupem największą liczbę nieprzyjaciół, a opadając z sił, myślał, by paść pośród swoich i nie

50 Dzielni wodzowie: Plut. Thes. 6.2, 30.1; Lyc. 23.1; Arist. 5.2, 14.3, 15.4; Them. 17.1, 22.2, 28.3, 31.4; Cim. 1.1, 3.1, 5.1, 5.3, 7.5, 13.3, 18.6; Per. 7.1, 10.2, 11.2, 18.1, 38.3; Nic. 6.2, 9.2, 15.1, 18.6; Alc. 10.2, 16.3, 18.4, 34.4, 35.2, 38.2; Lys. 2.1-2, 3.2, 7.1, 23.2, 24.3-4, 30.2; Ages. 16.2, 23.5, 34.6; Pel. 7.2, 19.4; Dio 52.2; Tim. 3.2, 7.2, 19.1, 21.3, 32.1, 36.2; Dem. 14.1, 20.1-2; Alex. 2.3, 3.2, 5.3, 8.2, 11.2, 23.2, 32.2, 33.6, 45.3, 48.1, 58.1-3; Phoc. 3; Demetr. 1.7, 50.3; Pyrrh. 4.3, 7.4, 8.1, 11.3, 15.4, 16.7, 20.1, 22.6, 26.4, 30.5; Arat. 24.2, 36.3; Agis 15.1; Cleom. 1.3, 4.5, 16.2, 28.1, 36.4, 37.4; Rom. 2.4, 6.3, 25.4; Cor. 4.2, 10.3; Publ. 17.2; Cam. 10.5; Marc. 1, 26.1; Flam. 7.3, 13.2, 21.3, 21.8; Fab. 3.3, 5.1, 13.4; Aem. 7.2, 12.1, 36.1; Cat. Ma. 1.1, 1.5, 3.1, 14-15, 20.6, 27.4; TG 1.5, 2.1, 3, 4.4; Mar. 2.1, 9.3, 7.1, 20.6, 28.2, 42.3; Sull. 5.1, 6.2, 11.3, 15.3, 29.2, 34.5; Sert. 1.4, 4.2, 3.3; Luc. 2.1, 3.4, 28.8, 33.1, 36.5; Crass. 29.5; Pomp. 1.1, 1.3, 8.6, 9.1, 13.6-7, 17.1, 50.1; Caes. 15, 17.2, 19.3, 20.5, 27.3, 38.3, 56.1; Cat. Mi. 8.1, 9.2; Brut. 29.6, 53.1; Ant. 3.5, 8.2, 7.1, 17.2-3, 42.2, 70.1; Comp. Ag. Gracch. 3.

51 Plut. Luc. 29.5.

52 Plut. Ant. 68.3.

53 Plut. Per. 27.2.

54 Plut. Arist. 16.4.

55 Plut. Alex. 57.2.

56 Plut. Agis. 14.1.

57 Plut. Sull. 27.5.

58 Plut. Dem. 20.1-2. 
dostać się w ręce wroga, a także taki, który bronił stanowiska, choć roztrzaskano mu hełm na głowie. Jednak już zapał śmiałka zdobywającego okręt pomimo odciętej ręki czy innego bohatera uparcie walczącego ze strzałą $\mathrm{w}$ oku, rannego w ramię i udo, to jak zauważa Plutarch - wynik dobroczynnego wpływu Cezara na wojsko ${ }^{59}$. W istocie, mechanizm uaktywniania żołnierskiej odwagi zdaje się w Plutarchowej regule uruchamiać wódz. Nie wydaje się, by samo męstwo żołnierzy mogło stanowić o militarnym sukcesie, jak w czasach Tukidydesa, gdy ateńscy hoplici mieli odwagę we krwi, a ich dzielny duch był niezmienny ${ }^{60}$. W pojęciu Plutarcha, który był obciążony hellenistycznymi innowacjami, takimi jak kult zwycięskiego wodza czy kult Tyche (utożsamionej z rzymską Fortuną), zwycięstwo na polu bitwy to raczej wynik kombinacji różnych elementów, najczęściej dwóch lub trzech spośród trzech kategorii: 1) mądry plan wodza, jego zręczność strategiczna, rozum, niezwykły umysł, męstwo wodza, zapał wodza; 2) szczęście; 3) męstwo żołnierzy, zapał żołnierzy, siła armii. Dobrym przykładem jest Tymoleon, którego sukcesu Plutarch upatruje w różnych konfiguracjach: najpierw w większym stopniu w roztropności (pronoia) i męstwie (aretē) wodza niż w szczęściu, potem w samym szczęściu (tychē), a jeszcze później w większym stopniu w szczęściu niż sile (dynamis) armii, w równym udziale szczęścia wodza i dzielności walczących (andragathia), w błyskotliwości (deinotēs) wodza i szczęściu, w męstwie i szczęściu wodza (aretē kai tychēe ${ }^{61}$. Nie istnieje przy tym w pojęciu Plutarcha bezpośrednia korelacja między wojskiem a szczęściem. W Żywocie Sulli mowa jest o obrazie przedstawiającym Tymoteusza, który śpi, podczas gdy Tyche łowi za niego miasta do sieci - nie pada ani jedno słowo o armii ${ }^{62}$. Wojenne szczęście $(t y c h \bar{e})$ zdaje się prawie wyłącznie elementem składowym sukcesu wodzów. Co najwyżej w niewielkim zakresie korzystają z niego jednostki polityczne, w tym głównie Rzymianie ${ }^{63}$.

Obrazy przedstawiające karnych żołnierzy w Żywotach to raczej migawki niźli element standardowego opisu. Widzimy hoplitów pod Platejami wykazujących ogromne opanowanie pośród wrogich pocisków w oczekiwaniu na pozytywne wróżby i rozkaz Pauzaniasza ${ }^{64}$. Dowiadujemy się o wojsku pod dowództwem Kimona, Lizandra, Kleomenesa utrzymanym w godnej podziwu dyscyplinie (kosmos) czy o posłusznych „mułach Mariusza” ${ }^{55}$. Jak na poziomie szczegółów prezentowali się

59 Plut. Pyrrh. 28.4; Sull. 14.2; Caes. 16.1-2; por. Apoph. Lac. 51.15.

${ }^{60}$ Thuc. 1.121.4, 2.39.4, 2.87.2.

${ }_{61}$ Plut. Tim. 19.1, 20.1, 20.5, 21.3, 36.2; por. Plut. Them. 15.2; Nic. 2.4, 6.2, 17.3, 18.5; Alex. 20.4; Cleom. 26.4; Sull. 6.3-7, 19.5; Pomp. 50.2; Luc. 29.5, 33.1.

62 Plut. Sull. 6.3.

63 Plut. Nic. 27.4; Pel. 25.1; Crass. 26.6; por. De Fort. Rom.; autorzy licznych prac poświęconych pojęciu tychē w dziełach Plutarcha nie poruszają problemu jego związku z żołnierzami, zob. F.E. Brenk, S.J., In Mist Apparelled. Religious Themes in Plutarch's Moralia and Lives (rozdział The Force of the Cause Whirled about in Disorder and Unrestrictedly: Daimon and Tyche in Plutarch), Leiden 1977, s. 145-183; S. Swain, Plutarch: Chance...; W.J. Tatum, Another Look at Tyche in Plutarch's Aemilius Paulus-Timoleon, „Zeitschrift für Alte Geschichte” 2010, 59, s. 448-461; F.B. Titchener, Fate and Fortune [w:] A Companion to Plutarch, red. M. Beck, Oxford 2014, s. 479-487.

${ }^{64}$ Plut. Arist. 17.5-8.

65 Plut. Cim. 6.1; Lys. 10.5; Cleom. 18.4; Mar. 13.2, 14.2. 
zdyscyplinowani żołnierze, możemy sobie wyobrazić na podstawie opisu lacedemońskiego wojska Agisa - maszerujący w ciszy, bez wyrządzania szkód, awantur, zachowujący porządek i piękny wygląd. Analogiczny widok przedstawiała armia rzymska ciągnąca na Partów pod rozkazami Antoniusza - szli w równych odstępach, bez hałasu, w milczeniu potrząsając pilami ${ }^{66}$. Wydaje się, że Plutarch za wzorowo zdyscyplinowaną armię, przynajmniej spośród greckich i tych dowodzonych przez królów, uważał wyłącznie żołnierzy spartańskich, jak bowiem sam zauważa, jedynie za wojskiem spartańskim nie ciągnęły trupy mimów, kuglarzy, tancerek i śpiewaczek, a w związku z tym nie było tu miejsca na rozwiązłość (akolasia), błazenady (bōmolochia) i ostentację (panēgyrismos) ${ }^{67}$.

Choć Plutarch znajduje upodobanie w opisywaniu nadzwyczajnych zjawisk przyrodniczych towarzyszących wojnom - od kichnięcia przy składaniu krwawej ofiary po upadek meteorytu w miejscu walki - to jednak stara się znaleźć równowagę między lekceważeniem znaków a naiwnym lękiem przed nimi ${ }^{68}$. $\mathrm{O}$ ile przedstawieni przez niego wodzowie prezentują całe spektrum poglądów niezależnie od epoki historycznej - od skrajnie bogobojnego Nikiasza, poprzez krytycznego Peryklesa, aż po pełnego lekceważenia Sullę - o tyle w przypadku żołnierzy, zarówno greckich, jak i rzymskich, mamy do czynienia raczej z jednym określonym typem niezmiennym w czasie. Jest to żołnierz bogobojny, skłonny do wiary we wszelkie znaki, z gotowością do popadnięcia w zabobonny strach (deisidaimonia). Przekonanie żołnierzy do walki przy niesprzyjających wróżbach mogło stanowić prawdziwe wyzwanie dla dowódców. Wygłaszali wówczas mowy, w których przekonywali, że znaki są korzystne, izolowali wróżbitów od żołnierzy lub nawet posuwali się do oszustwa, jak Agesilaos, który spreparował zwierzęcą wątrobę z napisem „zwycięstwo" ${ }^{69}$. W skrajnym przypadku, przedstawionym w Żywocie Brutusa, żołnierze, dostrzegając omen, byli zdolni do morderstwa - rozerwali na strzępy Etiopczyka, który wszedł przez obozową bramę ${ }^{70}$. Do bezbożnego czynu, czyli napaści na miejsce święte, mogłaby skłonić żołnierzy jedynie żądza zgromadzonych tam łupów ${ }^{71}$.

O ile dobry żołnierz to postać w Żywotach raczej bezbarwna, pozbawiona wyraźnych konturów, gdyż stanowiąca tło dla wodza, o tyle zły żołnierz przybiera wyraziste kształty i staje się niezależny od dowódcy. Przede wszystkim będzie to chciwiec i buntownik, a także - w bardzo ogólnym zarysie - tchórz i brutal.

O głównych bohaterach Żywotów możemy powiedzieć, że wielokrotnie zachowują dystans w stosunku do wojennej zdobyczy, należnej im odwiecznym prawem wojny. Żołnierze rzucają się na nią bez wahania. Na widok potencjalnych łupów

66 Plut. Agis 14.2; Ant. 39.4.

67 Plut. Cleom. 12.

68 Plut. Alex. 75.2; por. Per. 6.1; Cam. 6.4-6; Sert. 11.3; o poglądach Plutarcha na temat znaków i wróżb wyczerpująco: P. Veyne, Imperium grecko-rzymskie, przeł. P. Domański, Kęty 2008, s. 634682 (rozdział Plutarch. Problemy religijne inteligentnego poganina).

${ }_{69}$ Na przykład: Plut. Arist. 17.5-8; Nic. 23; Dio 24.1-3; Tim. 8-9.1, 26; Marc. 6.6; Flam. 7.5; Fab. 4.3; Mar. 17.3; Luc. 8.6; Brut. 39.3; Apoph. Lac. 2.77.

70 Plut. Brut. 48.2.

${ }^{71}$ Plut. Nic. 16.6; Demetr. 30.1; Sull. 12.3; 16.4 . 
ujawnia się w nich chciwość i gwałtowna zachłanność, jak u barbarzyńskich Galów, których Plutarch nazywa plemieniem o nienasyconym (aplēstos) pragnieniu bogactwa ${ }^{72}$. Bogactwo mogło mieć dla żołnierzy większą wartość niż zwycięstwo, a porzucenie pościgu za wrogiem czy zamieszki w obozie z powodu łupów wcale nie należały do rzadkości ${ }^{73}$. Wydaje się, że Plutarch potrzebę grabienia i plądrowania uważa za stałą cechę żołnierską, niezależnie od czasu i miejsca. Nawet żołnierze spartańscy jej ulegali, toteż Likurg miał zabronić zdzierania uzbrojenia z zabitych wrogów, aby żołnierze, szukając łupu, nie zaniechali bitwy ${ }^{74}$. Arystydes nie do końca skutecznie powstrzymał żołnierzy przed łupieniem perskich skarbów po bitwie pod Maratonem ${ }^{75}$. Nikiasz nie dopuścił, by ateńscy żołnierze rozgrabili cenne dary wotywne w syrakuzańskiej świątyni Zeusa Olimpijskiego, choć bardzo chcieli ją zając $^{76}$. Macedońskich żołnierzy Plutarch porównuje do psów (kynes), które węszą ślady skarbów (w Żywocie Pelopidasa Tebańczycy to młode psy), a przywiązanie żołnierzy z Krety do bogactwa przywołuje mu na myśl pszczoły (melittai) ciągnące do miodu ${ }^{77}$. W Żywocie Aleksandra mamy kolejne skojarzenie żołnierza ze zwierzęciem, tym razem pociągowym - macedoński król z niesmakiem obserwował, jak jeden z jego żołnierzy sam wziął na barki łupy, gdy muł zmęczył się ich dźwiganiem $^{78}$. Żołnierze Lukullusa byli tak ociężali od bogactwa i zbytku, że utracili zdolność walki ${ }^{79}$. Tysiące wojaków Pompejusza, ku jego zdziwieniu, przez kilka dni kopało i przewracało ziemię w poszukiwaniu skarbów ${ }^{80}$. Żołnierze Antoniusza nocą tak mordowali się wzajemnie, rozszarpując kosztowne łupy, że zrodziło się posądzenie o napaść wroga na obóz i sam wódz zawczasu prosił, by poderżnięto mu gardło, aby nie dostał się żywy w ręce wroga ${ }^{81}$. Nawet sam Plutarch zdaje się przez chwilę ulegać pięknemu i wspaniałemu widokowi łupów wojennych, gdy pisze o stosie kartagińskich skarbów leżących dookoła namiotu Tymoleona, gdzie zgromadzono między innymi tysiąc pancerzy kunsztownej roboty i dziesięć tysięcy tarcz ${ }^{82}$. Liczba miast i obozów wojskowych, które stały się lub miały stać ofiarą żołnierskiej grabieży, jest w Żywotach ogromna. Oczywiście największe wrażenie na wojsku robił widok złota i srebra, które w dużej ilości skłaniało do ignorowania przedmiotów ze spiżu i żelaza. Widok, który odbierał żołnierzom rozum, to obładowane złotem muł, koń

72 Plut. Pyrrh. 26.6.

73 Plut. Nic. 17.6, 27.5; Tim. 24.3; Alc. 30.4; Lys. 9.4; Ages. 22.1; Dem. 7.3, 9.5, 31.1-2; Alex. 20.6; Eum. 8.5-6; Demetr. 44.7; Pyrrh. 27.1; Arat. 18.2-4, 31.3-32.3; Cor. 9.1; Marc. 19; Flam. 5.1; Cat. Ma. 3.5-6; Aem. 29.1-31.4; Mar. 27.4; Sull. 14.3, 16.4, 28.2; Luc. 7.1, 14.1, 17.5-7, 19.3-4; 24.8, 29.2-3, 30.4, 35.4, 35.6; Pomp. 11.3-4; Sert. 19.4-5, 24.4; Crass. 2.7-8; Ant. 48; Brut. 46.1; Galb. 24.1; Regum 27.12 .

74 Plut. Apoph. Lac. 53.31.

75 Plut. Arist. 5.6.

76 Plut. Nic. 16.6.

77 Plut. Pel. 15.3; Alex. 24.1-2; Aem. 23.4.

78 Plut. Alex. 39.2.

79 Plut. Luc. 30.4.

80 Plut. Pomp. 11.3-4.

81 Plut. Ant. 48.

82 Plut. Tim. 29.1-2. 
lub wielbłąd. Wpuszczony między szeregi wrogiej armii, mógł być bardzo skuteczną bronią ${ }^{83}$. Przedmioty żołnierskiego pożądania to raczej nie broń, chyba że pozłacana i zdobiona klejnotami, ale przede wszystkim złote kielichy, takie mieszalniki, bransolety, naszyjniki, cenne kamienie, purpurowe szaty, monety, w mniejszym stopniu ludzie (niewolnicy) ${ }^{84}$. Sytuacje, w których żołnierze wykonują zadanie bojowe, ignorując skarby, wydawały się Plutarchowi godne odnotowania, ponieważ były rzadkie. Godnym uwagi wyjątkiem pozostaje armia Aleksandra Macedońskiego, która w drodze do Indii, zbyt ociężała z powodu obfitości łupów, część bogactwa rozdała, a część zniszczyła. Niewielu żałowało łupów, pisze Plutarch i podkreśla, że stało się to wszystko pod wpływem siły wyższej ${ }^{85}$, tym samym wykluczając żołnierską inicjatywę.

Drugą istotną skazą żołnierzy było ich niezdyscyplinowanie i buntowniczość przejawiające się skłonnością do rozruchów, tak że mogli przywodzić nawet na myśl rozbójników ${ }^{86}$. Przykładów żołnierskiej bezkarności jest w Żywotach znacznie więcej niż obrazów wojska karnego. Brak dyscypliny (ataxia, anarchia) to - jak sygnalizuje Plutarch - cecha armii barbarzyńskich (barbarikos) ${ }^{87}$, więc niewątpliwie klasyfikowany był jako wielka ułomność. Widzimy żołnierzy, zarówno greckich, jak i rzymskich, choć tych pierwszych rzadziej, demonstracyjnie odmawiających walki, opuszczenia obozu, rozchodzących się po okolicy, niezachowujących porządku w marszu, wszczynających awantury w obozie, targających namioty, knujących w namiotach, wypowiadających obelżywe słowa, nienawidzących wodza, lżących dowódców, krzyczących, lamentujących, płaczących, jęczących, hałasujących, żądających, upijających się, groźnie chrzęszczących bronią, zachowujących się arogancko w stosunku do miejscowej ludności. Powodem najczęściej były puste żołnierskie sakiewki, choć nie zawsze: Spartanin Amomfaretos ${ }^{88} \mathrm{w}$ czasie zmagań pod Platejami rzucił pod nogi Pauzaniasza wielki kamień, protestując przeciwko tchórzostwu wodza. Kiedy indziej znów Spartanie nie mieli ochoty (okneō) do szturmu. Znów ateńscy żołnierze Konona, zamiast gotować się do walki, rozeszli się po rynku, zwiedzali okolicę, spali lub jedli ${ }^{89}$. Najczęściej jednak buntownik to po prostu napastliwy chciwiec.

83 Na przykład: Plut. Lyc. 30.1; Arist. 5.6; Cim. 9.2-3; Nic. 16.6; Tim. 29; Alex. 12.1-2, 24.2, 39.2; Cat. Ma. 10.4; Marc. 19.1-2; CG 2.5; Luc. 7.2; 17.5, 29.3, 34.3; Mulier. virt. 22.

${ }_{84}$ Plut. Cim. 9.2-3; Ages. 9.5; Alex. 36, 40.1, 67.2; Eum. 9.3; Demetr. 7.3; Aem. 23.4, 30.2; Mar. 27.4; Luc. 34.2-3; Sert. 19.4-5; Caes. 27.4; Ant. 48.2.

85 Plut. Alex. 57.1-2; por. 43.1.

86 Plut. Sert. 18.1.

87 Plut. Pyrrh. 16.4-5; Sert. 16.1.

88 Plutarch pisze, że Amomfaretos postanowił pozostać na miejscu z ludźmi ze swego oddziału (Plut. Arist. 17.1-3). Herodot nazywa Amomfaretosa lochagiem, ale nieco później jego imię pojawia się wśród młodzieńców (eirenes): Hdt. 9.53.2, 9.85.1-2, a więc byłby to zwykły żołnierz, zob. R. Kulesza, Sparta w V-IV w. p.n.e., Warszawa 2003, s. 160-161.

89 Plut. Arist. 17.1-3; Nic. 24.3; Lys. 5.2, 11.4, 22.2; Dio 41.1; Phoc. 12, 25, 26.1; Alex. 62.3, 71; Eum. 6.3; Demetr. 44.3; Arat. 47.1; Fab. 20.3; Sull. 12.7-8; Sert. 3.3-4, 24.3-4; Crass. 30.4-5; Luc. 19.3, 24.3, 30.3-31.1, 35.3-4; Pomp. 3.3, 10.7, 13.1-2, 14.5, 39.1; Cic. 6.2; Oth. 5.3-5; por. De cohib. ira 9-10. 
Stosunkowo niewiele pisze Plutarch o żołnierskim tchórzostwie. Pokonany przeciwnik regularnie ucieka z pola bitwy, walczący ze strachu odwracają się od wroga i unikają walki, jednak Plutarch rzadko nazywa takie zachowanie tchórzostwem (deilia , apodeilia, atolmia), a żołnierzy - tchórzliwymi (deilos, atolmos $)^{90}$. Paniczny strach (phobos) - jak wyjaśnia Plutarch - generujący lęk przed hańbą i utratą dobrej sławy, choć dość często gości na kartach Żywotów, stosunkowo rzadko wywołuje asocjację z żołnierzami ${ }^{91}$.

Żołnierze brutale pojawiają się w Żywotach prawie wyłącznie jako horda plądrująca miasto w poszukiwaniu łupów i niszcząca przy tym wszystko, co napotka na swojej drodze. Częstokroć pokazani są z pochodniami w dłoniach, podpalający dobytek swoich ofiar ${ }^{92}$. Jednak nawet takich żołnierzy Plutarch nie obdarza określeniem omos (dziki, okrutny, krwawy). Niewielu wśród atakujących żołnierzy rozpoznajemy gwałcicieli i oprawców dzieci. Jako gwałciciel został opisany przede wszystkim dowódca Traków na usługach Aleksandra Macedońskiego, ukarany zresztą śmiercią przez samą ofiarę. Żołnierze, którzy mu towarzyszyli, rozkradali w tym czasie jej mienie ${ }^{93}$. W całych $\dot{Z}$ ywotach zniewolonych przez żołnierzy kobiet i dzieci (gynaikas kai paidas) czy żon i córek (gynaikas kai tas thygateras) nie jest wiele. Szczególnie wymowna jest scena w Żywocie Aratosa, w której prości żołnierze (stratiōtai) rozproszyli się po domach w poszukiwaniu dóbr materialnych, a dowódcy (hēgemones, lochagoi) niewolili żony i córki Pelleńczyków, zakładając im na głowy swoje hełmy w celu oznaczenia zdobyczy ${ }^{94}$.

W niewielkim stopniu Plutarcha interesują żołnierze zwolnieni ze służby i udający się do swoich domów. Nie spotykamy weteranów wojennych snujących przy stole wspomnienia, nawet czyniący to Kimon jest wyjątkiem ${ }^{95}$. Taki żołnierz jest bohaterem antycznej komedii. $Z$ całą pewnością biograf uważał chełpliwość za żołnierską przywarę, gdyż w dziele poświęconym zagadnieniu samochwalstwa za przykład daje właśnie żołnierza ${ }^{96}$. W Żywotach jednak megalanchia nie jest eksponowana na najniższym żołnierskim poziomie. Niektórzy wodzowie mają ów nieprzyjemny nawyk charakterystyczny właśnie dla zwykłego żołnierza - jak podkreśla Plutarch ${ }^{97}$.

Jak wynika z powyższej analizy, Żywoty Plutarcha nie odbiegają w znacznym stopniu od literackiego toposu każącego dostrzegać w żołnierzu istotę w niewielkim

90 Plut. Ages. 9.4; Dio 22.4; Tim. 25.3; Phoc. 25.2; Alex. 13.3; Mar. 23.4, 33.3; Crass. 10.2, 19.5; Brut. 46.5; Ant. 39.7; Regum 27.12.

91 Plut. Cim. 12.2; Per. 35.1; Ages. 17.3; Pel. 17.4; Alex. 27.1; Eum. 15.5; Cleom. 9.3; Cam. 23.6, 41.6; Fab. 6.7, 8.2; Marc. 18.4; Cat. Ma. 13.2, 14.2; Mar. 23.1; Sull. 21.4; Pomp. 7.2; Luc. 17.2; Crass. 26.3; Cat. Mi. 9.3.

92 Plut. Ages. 31.3; Dio 44.3-4, 46; Arat. 9.1; Cleom. 25.1; Phil. 14.4; Cor. 28.3; Marc. 19; Fab. 22.4-5; Aem. 29; Mar. 44.6; Sull. 14.3-4, 9.6; Luc. 19.3-4, 29.3; Crass. 17.3.

93 Plut. Alex. 12; por. Mulier. virt. 13, 22.

94 Plut. Sol. 8.6; Dio 41.3, 44.3; Arat. 31.3.

95 Plut. Cim. 9.

96 Plut. De se ipsum 21-22.

97 Plut. Alex. 23.4; Cat. Ma. 14.2; Aem. 12.3; Ant. 4.2; zob. S. Xenophontos, Comedy in Plutarch's Parallel Lives, „Greek, Roman, and Byzantine Studies” 2012, 52, s. 603-631 - autorka, analizując w Żywotach miles gloriosus, prezentuje jedynie postacie wodzów w roli żołnierzy. 
stopniu zdolną do kontrolowania własnych instynktów, a której wartość w dużej mierze zależy od kierującego nim dowódcy. Nie ma powodów przypuszczać, że Plutarch był szczególnie uprzedzony do żołnierzy jako takich. Nie obracał się w środowisku żołnierskim, nie dowodził armią, a jeśli bywał na polach bitew, to tylko w poszukiwaniu śladów zmagań militarnych z odległych czasów. Akcentowanie u żołnierzy chciwości mogło po części wynikać z Plutarchowego przekonania, że jest to najhaniebniejsza choroba ludzkości ${ }^{98}$. Biograf na każdym kroku czuł się w obowiązku rozprawiać o drzemiącym w Grekach i Rzymianach groźnym umiłowaniu bogactwa (pleonexia, philoploutia), o czym świadczy nagromadzenie we wszystkich jego pismach słów chrysion i argyrion wraz z odpowiednimi przymiotnikami. Rodzi się pytanie o obiektywizm Plutarchowej prezentacji żołnierskiego świata, o jej wartość historyczną. Jeszcze raz należy podkreślić, że wizja Plutarcha pozostaje w niewątpliwej zależności od źródeł, z których korzystał, a do których w dużej mierze dziś nie mamy już dostępu - wiele barwnych anegdot i scen z udziałem żołnierzy przetrwało właśnie dzięki jego dziełu. Nie będzie przesadą stwierdzenie, że na antycznych żołnierzy patrzymy bardzo często przez pryzmat Żywotów równoległych, niezależnie od oryginalnego wkładu Plutarcha w kreowanie żołnierskiego stereotypu, trzeba bowiem przypomnieć, że dzieło to cieszyło się przez wiele wieków ogromną popularnością i wywarło przemożny wpływ na kształtowanie obrazu greckiej i rzymskiej historii.

\section{BIBLIOGRAFIA}

Blois L. de, Crossing Status Barriers: the Disruption of an Imperial Banquet by Angry Soldiers in Plutarch's Otho [w:] Symposion and Philantropia in Plutarch, red. J.R. Ferreira, D. Leao, M. Tröster, Coimbra 2009, s. 223-229.

Blois L. de, Soldiers and Leaders in Plutarch's Galba and Otho [w:] A Roman Miscellany. Essays in Honer of Anthony R. Birley on his Seventieth Birthday, red. H.M. Schellenberg, V.E. Hirschmann, A. Krieckhaus, Gdańsk 2008, s. 5-13.

Blume H.D., Komische Soldaten. Entwicklung und Wandel einer typischen Bühnenfigur in der Antike [w:] Rezeption des antiken Dramas auf der Bühne und in der Literatur, red. B. Zimmermann, Stuttgart-Weimar 2001, s. 175-195.

Bravo García A., El pensamiento de Pluraco acerca de la paz y de la guerra, „Cuadernos de Filología Clásica" 1973, 5, s. 141-191.

Brenk F.E., S.J., In Mist Apparelled. Religious Themes in Plutarch's Moralia and Lives, Leiden 1977.

Brink L., Soldiers in Luke-Acts. Engaging, Contradicting, and Transcending the Stereotypes, Tübingen 2014.

Fuhrmann F., Les images de Plutarque, Paris 1964.

98 Plut. Agis 13.1; por. Lyc. 30.1; Sol. 20.2; Lys. 2.4; Demetr. 32.5; Crass. 2.1, 14.4; Luc. 17.5, 33.4; Cat. Mi. 52.4; Galb. 1.4; De Cup. 
Gray B., Reconciliation in Later Classical and Post-Classical Greek Cities: A Question of Peace and Peacefulness? [w:] Peace and Reconciliation in the Classical World, red. E. P. Moloney, M.S. Williams, New York 2017.

Hilton J., War and Peace in the Ancient Greek Novel, „Acta Classica” 2005, 48, s. 57-85.

Hornblower S., Warfare in Ancient Literature: The Paradox of War [w:] The Cambridge History of Greek and Roman Warfare, vol. I, red. P. Sabin, H. van Wees, M. Whitby, Cambridge 2008, s. 22-53.

Jones C.P., Plutarch and Rome, Oxford 1971.

Kennell N.M, The Greek Ephebate in the Roman Period, „,The International Journal of the History of Sport" 2009, 26, s. 323-342.

Kulesza R., Sparta w V-IV w. p.n.e., Warszawa 2003.

Kyrychenko A., The Roman Army and the Expansion of the Gospel: The Role of Centurion in Luke-Acts, Berlin 2014.

MacCary W.T., Menander's Soldiers: their Names, Roles and Masks, „American Journal of Philology" 1972, 93, s. 279-298.

Marincola J., History Without Malice: Plutarch Rewrites the Battle of Plataea [w:] Brill's Companion to the Reception of Herodotus in Antiquity and Beyond, red. J. Priestley, V. Zali, Leiden-Boston 2016, s. 101-119.

Pelling C.B.R., Plutarch and History. Eighteen Studies, Oxford 2002.

Roesch P., Une loi fédérale béotienne sur la préparation militaire [w:] Acta of the Fifth International Congress of Greek and Latin Epigraphy, Oxford 1971, s. 81-88.

Russell D.A., Plutarch, London 1972.

Schettino M.T., The Use of Historical Sources [w:] A Companion to Plutarch, red. M. Beck, Malden Mass.-Oxford 2014, s. 417-436.

Stadter P.A., Plutarch and His Roman Readers, Oxford 2014.

Swain S., Plutarch: Chance, Providence, History, „American Journal of Philology” 1989, 110, s. 272-302.

Swain S.C.R., Hellenic Culture and the Roman Heroes of Plutarch, „Journal of Hellenic Studies" 1990, 110, s. 126-145.

Tatum W.J., Another Look at Tyche in Plutarch's Aemilius Paulus-Timoleon, „Zeitschrift für Alte Geschichte" 2010, 59, s. 448-461.

Titchener F.B., Fate and Fortune [w:] A Companion to Plutarch, red. M. Beck, Oxford 2014, s. 479-487.

Veyne P., Imperium grecko-rzymskie, przeł. P. Domański, Kęty 2008.

Wardman E.A., Plutarch's Methods in the Lives, „Classical Quarterly” 1971, 21, s. 253-261.

Wheeler E.L., The General as Hoplite [w:] Hoplites. The Classical Greek Battle Experience, red. V.D. Hanson, London-New York 1991, s. 121-170.

Whitmarsh T., Alexander's Hellenism and Plutarch's Textualism, „Classical Quarterly” 2002, 52, s. 174-192.

Wysk H., Die Gestalt des Soldaten in der griechisch-römischen Komödie, Giessen 1921.

Xenophontos S., Comedy in Plutarch's Parallel Lives, „Greek, Roman, and Byzantine Studies" 2012, 52, s. 603-631.

Zampaglione G., L'idea della pace nel mondo antico, Torino 1967.

Ziegler K., Plutarchos [w:] Paulys Realencyclopädie der classischen Altertumswissenschaft (RE) RE 22, 1 (1951), s. 636-962. 